\title{
Leszek Józef Wiśniewski - wspomnienie o Przyjacielu
}

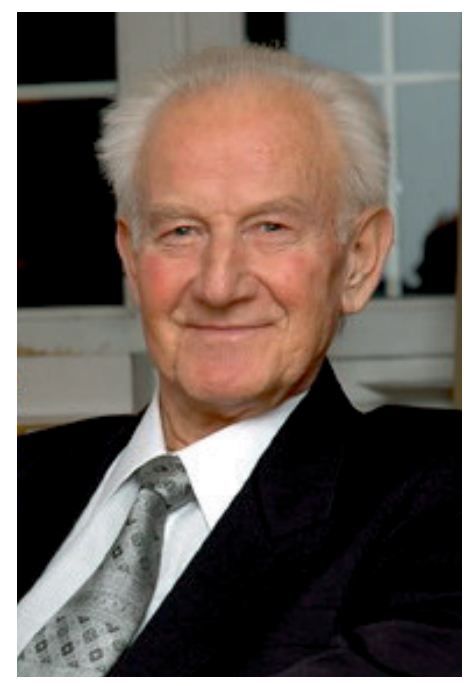

Bardzo ciężko przychodzi mi pisać w czasie przeszłym o Leszku Wiśniewskim. Całe moje życie zawodowe - pracownika naukowego Instytutu Nauk Prawnych PAN toczyło się niejako u jego boku.

Leszek urodził się w Świeciu nad Wisłą (19 lipca 1935 r.). Rodzice - Ewa (z domu Korthals) i Aleksander Wiśniewscy - byli nauczycielami na Pomorzu. Po maturze Leszek Wiśniewski zaczął studiować rybołówstwo, z których to studiów jednak zrezygnował. Przeniósł się do Poznania, gdzie ukończył prawo. Żona - Krystyna, razem przeżyli 50 lat. Absolwentka historii sztuki, wieloletni pracownik poznańskiego Pałacu Kultury (obecnie Centrum Kultury Zamek w Poznaniu). Kurator licznych wystaw i organizator spotkań artystycznych (w tym drugiej w Polsce wystawy World Press Photo). Córka, Paulina, dziennikarka prasowa i telewizyjna (TVP Poznań), nauczycielka, lektorka; autorka publikacji prasowych (artykułów, reportaży, felietonów). Brat profesor Henryk Mirosław Wiśniewski, należał do grupy najbardziej znanych neuropatologów Stanów Zjednoczonych. W czasie XI Międzynaro- 
dowego Kongresu Neuropatologów w Kyoto w 1991 r. profesor Wiśniewski został zaliczony do grona naukowców, których badania wniosły największy wkład do postępu wiedzy z zakresu neuropatologii w mijającym stuleciu. Laureat szeregu prestiżowych nagród naukowych oraz doktoratów honoris causa - Akademii Medycznych Gdańska, Poznania i College of Staten Island the City University of New York. Siostra Jadwiga mieszka we Wrocławiu.

Poznaliśmy się z Leszkiem na seminarium doktoranckim prowadzonym przez profesora Adama Łopatkę. Nasz Mistrz, którego między sobą zawsze nazywaliśmy „szefem”, miał znakomite wyczucie w doborze współpracowników. Leszek miał już zaawansowaną pracę doktorską, gdy dołączyłem do tego grona. Wszyscy zajmowaliśmy się rożnymi aspektami praw jednostki. W ówczesnej terminologii nie posługiwaliśmy się pojęciem praw człowieka. Leszek wniósł do naszego grona znajomość praktycznego funkcjonowania organów samorządu terytorialnego - był przez wiele lat radcą prawnym wspołpracującym z samorządami. Po ukończeniu studiów prawniczych pracował na rónych stanowiskach $\mathrm{w}$ administracji państwowej. Miał nawet krótki epizod pracy w cenzurze, co mu później gorliwi lustratorzy wypominali i co być może miało wpływ na to, że nie został wybrany do Trybunału Konstytucyjnego mimo, iż mial po temu wszelkie kwalifikacje. Praca doktorska obroniona na UAM w 1972 r. zaowocowała opublikowaniem bardzo dobrej monografii pt. Model prawny stowarzyszeń w PRL, która ukazała się nakładam wydawnictwa PWN w 1974 r. Kilka lat później w 1981 r. wydał nakładem Ossolineum książkę pt. Gwarancje podstawowych praw i wolności obywateli PRL. Praca ta, jak na ówczesne czasy, przynosiła niezwykle nowatorską i krytyczną zarazem analizę mechanizów ochrony praw jednostki. Na jej podstwie Leszek uzyskał habilitację w Instytucie Nauk Prawnych PAN. Tytuł profesora uzyskał w $1999 \mathrm{r}$.

Leszek całkowicie poświęcił się pracy naukowej oraz dydaktycznej. Do końca pracował w Poznańskim Centrum Praw Człowieka INP PAN. Był szefem Centrum w latach dziewięćdzisiątych. Był też cenionym nauczycielem akademickim na kilku uczelniach niepublicznych. Nigdy nie zabiegał o eksponowane stanowiska. Jednakże po obronie pracy habilitacyjnej postanowił wpisać się na listę adwokatów. Było to w latach osiemdziesiątych, kiedy zdobył już uznanie jako specjalista w zakresie praw jednostki. Ówczesny Dziekan Poznańskiej Rady Adwokackiej odpisał Leszkowi, że niestety nie mogą 
spełnić jego prośby gdyż jego specjalność naukowa nie mieści się w obszarze działalności adwokatury (!). Nieźle się wszyscy ubawiliśmy tą kuriozalną zaiste reakcją adwokatury na prośbę Leszka.

Leszek był autorem 114 publikacji w tym 5 książek oraz 30 ekspertyz. Był zarazem konsekwentym propagatorem ścisłego odróżniania praw jednostki od wolności jednostki. To wlaśnie jemu zawdzięczmy takie a nie inne normatywne ujęcie konstytucyjnej regulacji praw i wolności człowieka. Leszek powołany został do zespołu stałych ekspertów Komisji Konstytucyjnej Zgromadzenia Narodowego. Był bardzo pracowitym i aktywnym uczestnikiem prac Komisji i możemy zaliczyć go do grona „Ojców Konstytucji RP”. W uznaniu swojej roli w tym procesie został odznaczony przez Prezydenta RP Krzyżem oficerskim orderu Odrodzenia Polski.

W środowisku polskich konstytucjonalistów Leszka lubiano i poważano.

\section{Profesor Dariusz Górecki pisze:}

„Profesora Leszka Wiśniewskiego poznałem w 1979 r. na zjeździe Katedr i Zakładów Prawa Konstytucyjnego w Ślesinie. Rok później był organizatorem zjazdu Katedr w Kiekrzu. Niestety nie miałem okazji poznania go bliżej - nigdy Profesor nie był powołany na recenzenta w przewodzie doktorskim lub habilitacyjnym na Wydziale Prawa i Administracji Uniwersytetu Łódzkiego. Spotykaliśmy się więc sporadycznie, na zjazdach Katedr, na konferencjach lub przy różnych okazjach w Sejmie. Zapamiętałem go jako życzliwego dla młodszych kolegów, rzeczowego, wybitnego znawcę zagadnień wolności, praw i obowiązków człowieka i obywatela.

Wdzięczny mu jestem, że zgodził się wygłosić referat na XLV zjeździe Katedr Prawa Konstytucyjnego zorganizowanego przez ośrodek lódzki w 2003 r. w Spale. Referat Profesora pt.: Wolność prasy w świetle Konstytucji Rzeczypospolitej Polskiej, ustaw oraz wiążacego Polskę prawa międzynarodowego. Problemy podstawowe otwierał konferencję. Ze względu na poruszaną problematykę i tytuł konferencji: Wolność słowa w mediach był to w gruncie rzeczy referat wiodący. Wystąpienie Profesora interesujące i bardzo treściowe wzbudziło ożywioną dyskusję, toczącą się zwłaszcza wokół dwu wartości: wolności prasy i ochrony prywatności.

Odejście Profesora to wielka strata dla środowiska polskich konstytucjonalistów". 
Natomiast profesor Stanisław Bożyk tak zapamietał Leszka:

„Gdy otwierałem w ubiegłym roku obrady Zjazdu Katedr Prawa Konstytucyjnego w Augustowie, radowała mnie obecność kilku Naszych Seniorów. Nie dostrzegłem wśród nich Profesora Leszka Wiśniewskiego, którego pamiętałem $z$ aktywnego uczestnictwa praktycznie w każdym Zjeździe Katedr, w którym sam uczestniczyłem. A podczas tegorocznego Zjazdu w Toruniu dowiedziałem się, że Pan Profesor odszedł na zawsze z Naszego Grona. Jego śmierć to poważna strata dla nauki polskiego prawa konstytucyjnego, był On bowiem jednym z najbardziej cenionych badaczy statusu prawnego jednostki oraz autorem wielu znaczących opracowań naukowych z zakresu tej problematyki.

$\mathrm{Z}$ jedną z pierwszych prac naukowych Profesora Leszka Wiśniewskiego zapoznałem się zanim poznałem Go osobiście, a miało to miejsce w okresie stanu wojennego i z inspiracji... Profesor Janiny Zakrzewskiej. W październiku 1982 r. Pani Profesor rozpoczynała pracę w białostockiej Filii UW, co stało się w wyniku starań ówczesnego dziekana Profesora Jerzego Stembrowicza. Gdy zastanawialiśmy się nad wykazem literatury pomocniczej dla studentów, Pani Profesor zasugerowała, aby w zakresie problematyki praw i wolności obywateli wpisać do tego wykazu monografię L. Wiśniewskiego, Gwarancje podstawowych praw i wolności obywateli PRL, Wrocław 1981. Usłyszałem wówczas od Profesor Zakrzewskiej, że jest to bardzo rzetelne opracowanie i nie przesiąknięte nadmiernie „ideologią komunistyczną”. Taka opinia zachęciła mnie oczywiście do pośpiesznej lektury tej monografii. A Profesor Janina Zakrzewska wykładała w Białymstoku prawo konstytucyjne jedynie przez 3 miesiące, gdyż uczelniana organizacja PZPR nie zgodziła się na Jej dalsze zatrudnienie w Filii UW.

Profesora Leszka Wiśniewskiego zapamiętałem przede wszystkim z dwóch Zjazdów Katedr, na których występował w roli referenta. Po raz pierwszy miało to miejsce na Zjeździe w Kołobrzegu w 1989 r. Wygłosił on wtedy referat Gwarancje praw $i$ wolności obywatelskich w przyszłej konstytucji, w którym zaprezentował swoją wizję regulacji konstytucyjnej w tym zakresie, krytykując zarazem rozwiązania przyjęte w Konstytucji PRL. Z kolei na Zjeździe w Spale w 2003 r. był to referat Wolność prasy w świetle Konstytucji RP, ustaw oraz wiqżacego Polskę prawa międzynarodowego. Odnosząc się do wypowiedzi w dyskusji, zwrócił się wtedy do jednego z dyskutantów ze słowami „nie jestem 
przekonany, czy ma Pan rację. Niech Pan to jeszcze raz przemyśli”. Taki był właśnie Profesor Leszek Wiśniewski, którego klarownych wypowiedzi i trafnych uwag już nie usłyszymy”.

Profesor Andrzej Bisztyga tak wspomina Leszka:

„Profesora Leszka Wiśniewskiego znałem osobiście, chociaż muszę przyznać, że postrzegałem go głównie przez pryzmat jego naukowych i organizacyjnych dokonań a w mniejszym stopniu w oparciu o kontakty osobiste. Tak więc znam jego prace poświęcone głównie wolności słowa, prasy, wolności przemieszczania się czy ochronie praw człowieka i kwestii ich dopuszczalnych ograniczeń. W jego naukowych badaniach nad wolnościami i prawami jednostki zawsze mocno zarysowywał się konstytucyjny aspekt zagadnienia. Podkreślmy, że jako ekspert Komisji Konstytucyjnej Zgromadzenia Narodowego brał udział w pracach nad formułowaniem treści obowiązującej Konstytucji RP a zwłaszcza wywarł wpływ na kształt konstytucyjnego katalogu wolności i praw człowieka. Akcentował znaczenie rozróżnienia między prawami jednostki a jej wolnościami.

Od zawsze kojarzyłem Go z Poznaniem. Był przecież współzałożycielem Poznańskiego Centrum Praw Człowieka w Poznaniu, to jest jednostki, której znaczenia dla budowy i rozwoju - w kraju i poza jego granicami - środowiska prawników zajmujących się prawami człowieka, nie sposób przecenić. Jest to dla mnie ważne, ponieważ byłem uczestnikiem pierwszego Kursu praw człowieka zorganizowanego przez Centrum w 1992 r. i do dzisiaj przechowuję poświadczający to dyplom.

Zapadło mi w pamięci, jak w 1997 r. profesor Wiśniewski podarował mi swoją pracę dotyczącą wolności przemieszczania się i wyboru kraju zamieszkania. Pracę tę nadal posiadam w swojej bibliotece. Byłem wtedy już po doktoracie i było to dla mnie dużym przeżyciem, że naukowiec $\mathrm{z}$ takim dorobkiem i pozycją dostrzegł młodego adiunkta, który także w obszarze swych naukowych zainteresowań posadowił prawa człowieka. Miły klimat tego spotkania pamiętam do dzisiaj. Wspominam Go jako człowieka życzliwego, stonowanego, otwartego na wymianę argumentów, ale też umiejącego stanowczo bronić swych poglądów, które nie zawsze wpisywały się w dominujący nurt poglądów na kierunki rozwoju praw człowieka. W szeregu kwestii miał swoje własne poglądy, które potrafił klarownie uzasadniać i wyraźnie 
artykułować, by przytoczyć jego opinie na temat interpretacji konstytucyjnej definicji małżeństwa (art. 18 Konstytucji) czy na temat roli i zadań Rzecznika Praw Dziecka.

Działalność profesora Leszka Wiśniewskiego nie ograniczała się do czysto akademickich form działalności. Profesor przywiązywał wagę do praktycznych zastosowań i implikacji badań naukowych, stąd był także Autorem opinii i ekspertyz prawnych. Przyznaję, że jest to ta sfera aktywności zawodowej, którą i ja darzę pewnym zainteresowaniem czy wręcz sympatią.

Pamiętam profesora $\mathrm{z}$ rozmów prowadzonych zarówno w Poznaniu, jak i podczas różnych konferencji. Zauważmy, że nie zaniedbywał również Zjazdów Katedr i Zakładów Prawa Konstytucyjnego. Na podstawie tych kontaktów utrwalił mi się obraz Profesora jako człowieka po prostu pogodnego i życzliwego, chętnie dzielącego się swą wiedzą i doświadczeniem z młodszymi badaczami. Uważam, że Jego odejście jest dużą stratą dla naszego środowiska konstytucjonalistów, w tym tych koncentrujących się w swych badaniach na prawach człowieka.

W osobie profesora Leszka Wiśniewskiego odszedł od nas człowiek kochający swoją pracę, po prostu przyjacielski i - co pragnę podkreślić - życzliwy wobec młodszych kolegów, czego sam doświadczyłem. Będzie Go brakowało w naszym środowisku”.

Badania naukowe Leszka koncentrowały się na teoretycznej i prawnej problematyce praw człowieka w systemie prawa krajowego i międzynarodowego. Był autorem i współautorem kilku książek, kilkuset artykułów. Ostatnim osiągnięciem naukowym Leszka, z którego był zresztą bardzo dumny był udział w opracowaniu pierwszego w języku polskim komentarza do Międzynarodowego Panktu Praw Obywatelskich i Politycznych. Jako redaktor tej pracy pragnę podkreślić, że był niezwykle zdyscyplinowanym autorem i stanowił dla nas wszystkich wzór punktualności i rzetelności. Był też otwarty na krytykę i gotowy modyfikować swoje teksty gdy uznał trafność rzeczowej argumentacji.

Leszek Wiśniewski był pracowitym, ciepłym człowiekiem, oddanym swej pracy i rodzinie. Do wielu zalet Leszka nie można jednak zaliczyć umiejętności dobrego prowadzenia samochodu. Na dobrą sprawę nie chciał mieć samochodu, ale na skutek nalegań brata, który w latach osiemdziesiątych sfinalizował zakup Fiata 126 stał się osobą zmotoryzowaną. W tym czasie 
jego sąsiadkami była Hanna Suchocka mieszkająca obok w bloku i jej siostra Elżbieta Gajewska z mężem. Obie Panie też miały Maluchy. Któregoś dnia Leszek postanowił zaparkować samochód pomiędzy ich samochodami. Skończyło się to uszkodzeniem wszystkich trzech. Jak Elżbieta zwabiona chałasem zjawiła się na miejscu, Leszek wręczył jej kluczyki swojego samochodu i powiedział - „a teraz odjedź nim”. Straty wyrównał natychmiast z komentarzem „to nie będzie ostatnia kraksa”. I rzeczywiście kilka lat później zdarzyło mu się dachować jadąc z żoną. Samochód był zniszczony, ale pasażerowie jakimś cudem wyszyli bez szwanku. Gdy żona usiłowała wyjść z samochodu to Leszek zaczął ją strofować, żeby nie deptała po szybie bo ją uszkodzi.

Trzeba podkreślić, że Leszek był człowiekiem bardzo pogodnym, uśmiechniętym lubił żartować. Był przyjacielski i chętnie pomagał ludziom. Relaksował się czytając, jeżdżąc na rowerze czy pływając. Kochał kwiaty i słońce... W ostatnich latach delektował się urokami życia na działce czy też na słonecznym tarasie. Jednak długie godziny zwykle spędzał pochylony nad książkami, pracowicie coś pisząc, przygotowując recenzje, ekspertyzy czy wykłady. Pracował bowiem do końca życia.

Życzliwość, pogodę ducha i pracowitość - to pamiętać będą współpracownicy i rodzina Leszka Wiśniewskiego. Bo zostawił po sobie wiele dobrego...

Roman Wieruszewski 